\title{
Incidental Gall Bladder Adenocarcinoma in Cholecystectomy Specimens; A Single Center Experience and Review of the Literature
}

\author{
Bita Geramizadeh ${ }^{1,2,}$, , Ali Kashkooe ${ }^{3}$
}

\section{ABSTRACT}

1. Department of Pathology, Medical School of Shiraz University, Shiraz University of Medical Sciences, Shiraz, Iran

2. Transplant Research Center, Shiraz University of medical Sciences, Shiraz, Iran

3. Student Research Committee, Shiraz University of medical Sciences, Shiraz, Iran

\footnotetext{
* Corresponding Author:

Bita Geramizadeh, MD

Department of Pathology, Transplant Research Center, Shiraz University of Medical Sciences, Shiraz, Iran Telefax: + 987136473238

Email: geramib@gmail.com

Received: 21 Apr. 2018

Accepted: 12 Sep. 2018
}

\begin{abstract}
BACKGROUND
Gallbladder adenocarcinoma is the most common malignant tumor of the biliary tract. Most of gall bladder cancers are detected incidentally only after pathological examination of the surgical specimens. In this study we investigated the characteristics of incidental gallbladder cancers in our center and also reviewed the current literature regarding the diagnosis and treatment of such incidentally detected tumors in the gall bladder.
\end{abstract}

\section{METHODS}

We retrospectively reviewed all of the cholecystectomy specimens in the archives of Pathology Department in the hospitals affiliated to Shiraz University of Medical Sciences in the study period (2010-2016). Clinicopathological characteristics were extracted from the patients' clinical charts, which included symptoms, radiological findings, laboratory data, and surgical procedures as well as outcome.

\section{RESULTS}

During these 7 years we identified 18 cases of incidental gall bladder cancer, consisted of 13 women and 5 men with the age range of 32 to $85(62.5 \pm 14.2)$ years detected after pathological study of the resected gall bladders among more than 4800 resected gall bladders. During the period, only two patients were operated on with the impression of gall bladder adenocarcinoma, which was not included in the study. Ten cases were T1 and eight were T2 at the time of surgery. They have been followed up for 1-7 years, during which, six cases of T2 died. All of the T1 cases are alive and symptom free.

\section{CONCLUSION}

By increasing laparoscopic cholecystectomies in our center we observed $0.37 \%$ incidental cases of gall bladder adenocarcinoma. Preoperative diagnosis of this cancer in early stages is very difficult and needs high degree of suspicion. The most important predictor of prognosis is the stage of the cancer at the time of surgery. To the best of our knowledge, this is the first report of incidental gall bladder cancer from Iran.

\section{KEYWORDS:}

Incidental, Gall bladder, Adenocarcinoma, Cholecystectomy

Please cite this paper as:

Geramizadeh B, Kashkooe A. Incidental Gall Bladder Adenocarcinoma in Cholecystectomy Specimens; A Single Center Experience and Review of the Literature. Middle East J Dig Dis 2018;10:249-253. doi: 10.15171/mejdd.2018.118.

\section{INTRODUCTION}

Gallbladder cancer is relatively rare but constitutes the fifth most common gastrointestinal tract cancer and the most common cancer of the biliary system. Adenocarcinoma as the most common gall bladder malignancy harbors 
a poor prognosis. There are many cases of incidental gall bladder cancers operated on with the impression of benign diseases, mostly gall stones and cholecystitis. ${ }^{1}$ There are some reports from different areas of the world regarding the percentage and characteristics of incidental gall bladder cancers among cholecystectomies performed with the primary impression of benign diseases. ${ }^{2}$ In this study we discuss our experience in incidental gall bladder adenocarcinomas in our university-affiliated hospitals as the largest center of hepatobiliary surgery in south of the country and the first report from Iran.

\section{MATERIALS AND METHODS}

During 7 years (2010-2016) a total of 4872 adult patients underwent cholecystectomy in the hospitals affiliated to Shiraz University of Medical Sciences. The patients were 1827 men and 3045 women with the mean \pm SD age of $54 \pm 12$ years (range 29-81). Of them, 18 patients were diagnosed as having gallbladder adenocarcinoma after pathological studies of the surgical specimens. There were two more cases with the preoperative diagnosis of cancer, which were not included in this study. It means that more than $89 \%$ of the gall bladder cancers in our center were incidentally detected. Both gall bladder cancers with preoperative diagnosis (non-incidental cases) were in advanced stages with liver metastasis at the time of operation.

All the clinical characteristics of these patients (including imaging findings, laboratory findings, and patients' follow-up) were extracted from the clinical charts.

\section{RESULTS}

During the study period (2010-2016), there were 4872 patients who underwent cholecystectomy either by laparoscopy or open surgery with the clinical impression of cholelithiasis or cholecystitis. Of them, 18 (0.37\%) patients were incidentally diagnosed as having gall bladder adenocarcinoma after pathological study of the surgical specimens. They were 13 female and 5 male patients. Age of them was from 32 to $85(62.5 \pm 14.2)$ years. All of the patients presented with right upper quadrant abdominal pain. There were three patients presented with abdominal pain and jaundice, one with abdominal pain and anorexia, and another with abdominal pain and weight loss. All of the patients were non-smoker with no history of alcohol consumption.
The mean WBC count and serum hemoglobin were 1300-21100 (9244 \pm 4838) per $\mathrm{mL}$ and 8.2-13.3 (11.4 $\pm 1.4) \mathrm{gr} / \mathrm{dL}$, respectively. Alkaline phosphatase, ALT (Alanine aminotransferase), and AST(Aspartate aminotransferase) were $293.3 \pm 120.5,62.5 \pm 67$, and 46.6 $\pm 48.6 \mathrm{IU} / \mathrm{L}$, respectively. Table 1 shows the details of laboratory findings, clinical symptoms, and surgical treatment as well as survival in these 18 incidental gall bladder adenocarcinomas.

Imaging study before operation was ultrasonography in all of the 18 patients. In most of these 18 patients the gall bladders were normal in ultrasonography except in six patients in whom ultrasonography showed mild and insignificant gall bladder wall thickening. Eight patients had cholelithiasis as well. No polyp was found.

After pathological study and diagnosis, all of them were diagnosed as being moderately differentiated adenocarcinoma. After that, staging was done, which showed $\mathrm{T} 1$ in 10 patients and $\mathrm{T} 2$ in other 8 patients. In all of the patients with stage $\mathrm{T} 2$ re-operation was performed in less than 40 days after the primary cholecystectomy consisted of segmental hepatectomy, roux-en-y hepaticojejunostomy with or without hilar lymph node dissection. The patients were followed-up for 1 to 7 years. During these years, six patients died secondary to widespread cancer, bleeding, and other postoperative complications and the other 12 patients are still alive and symptomfree. Of the patients, all patients with $\mathrm{T} 1$ stage (10 cases) are alive and only two patients with stage $\mathrm{T} 2$ are alive at the time of study.

\section{DISCUSSION}

Gall bladder adenocarcinoma is the most common malignancy of the biliary tract. Increasing laparoscopic cholecystectomies as the gold standard procedure have caused more and more detection of incidental gall bladder cancers. ${ }^{3}$ Incidental gall bladder carcinoma has been defined as carcinoma of gall bladder detected for the first time after cholecystectomy and accidentally found on histological examination of the gall bladder. ${ }^{4}$

There are different reports about the frequency of incidental gall bladder adenocarcinoma in the patients who have undergone cholecystectomy for other reasons mostly benign lesions i.e. cholecystitis and cholelithiasis. Table 2 shows the different reports about the percentages 
Table 1: Clinicopathological characteristics of 18 incidental gall bladder adenocarcinomas

\begin{tabular}{|c|c|c|c|c|c|c|c|c|c|c|}
\hline $\begin{array}{l}\text { Age/ } \\
\text { Sex }\end{array}$ & Symptom & $\begin{array}{l}\text { Ultraso- } \\
\text { nography }\end{array}$ & 1ALP & 2ALT & 3AST & $4 \mathrm{WBC}$ & $5 \mathrm{Hb}$ & Stage & Second Surgery & Follow- up \\
\hline $59 / \mathrm{M}$ & $\begin{array}{l}\text { Abdominal } \\
\text { Pain }\end{array}$ & Stones & 270 & 46 & 44 & 5700 & 10.9 & $\mathrm{~T} 2$ & $\begin{array}{l}\text { Segmental hepatectomy, roux- } \\
\text { en-y hepaticojejunostomy and } \\
\text { hilar lymph node dissection }\end{array}$ & $\begin{array}{l}\text { Expired } 2 \text { months } \\
\text { after surgery }\end{array}$ \\
\hline $65 / \mathrm{F}$ & $\begin{array}{l}\text { Abdominal } \\
\text { Pain, } \\
\text { constipation }\end{array}$ & Stones & 175 & 14 & 15 & 21100 & 12.1 & $\mathrm{~T} 1$ & - & Alive \\
\hline $85 / \mathrm{M}$ & $\begin{array}{l}\text { Abdominal } \\
\text { Pain, } \\
\text { constipation }\end{array}$ & $\begin{array}{l}\text { Wall } \\
\text { thickening, } \\
\text { stones }\end{array}$ & 261 & 12 & 14 & 1300 & 12.2 & $\mathrm{~T} 1$ & - & Alive \\
\hline $70 / \mathrm{F}$ & $\begin{array}{l}\text { Abdominal } \\
\text { Pain, } \\
\text { constipation }\end{array}$ & Normal & 195 & 87 & 54 & 10800 & 10.3 & $\mathrm{~T} 1$ & - & Alive \\
\hline $59 / \mathrm{F}$ & $\begin{array}{l}\text { Abdominal } \\
\text { Pain }\end{array}$ & Normal & 286 & 30 & 28 & 8100 & 13.3 & $\mathrm{~T} 1$ & - & Alive \\
\hline $65 / F$ & $\begin{array}{l}\text { Abdominal } \\
\text { Pain, jaundice }\end{array}$ & $\begin{array}{l}\text { Wall } \\
\text { thickening }\end{array}$ & 302 & 143 & 101 & 11300 & 13.1 & $\mathrm{~T} 2$ & $\begin{array}{l}\text { Segmental hepatectomy, roux- } \\
\text { en-y hepaticojejunostomy and } \\
\text { hilar lymph node dissection }\end{array}$ & $\begin{array}{l}\text { Expired } 1 \text { day } \\
\text { after secondary } \\
\text { surgery }\end{array}$ \\
\hline $75 / F$ & $\begin{array}{l}\text { Abdominal } \\
\text { pain and } \\
\text { anorexia }\end{array}$ & $\begin{array}{c}\text { Wall } \\
\text { thickening }\end{array}$ & 529 & 21 & 31 & 5400 & 11.1 & $\mathrm{~T} 2$ & $\begin{array}{l}\text { Segmental hepatectomy, roux- } \\
\text { en-y hepaticojejunostomy and } \\
\text { hilar lymph node dissection }\end{array}$ & Alive \\
\hline $74 / \mathrm{F}$ & $\begin{array}{l}\text { Abdominal } \\
\text { Pain }\end{array}$ & $\begin{array}{c}\text { Wall } \\
\text { thickening }\end{array}$ & 218 & 85 & 79 & 16.6 & 9 & $\mathrm{~T} 1$ & - & Alive \\
\hline $53 / \mathrm{F}$ & $\begin{array}{l}\text { Abdominal } \\
\text { pain, weight } \\
\text { loss }\end{array}$ & $\begin{array}{c}\text { Wall } \\
\text { thickening }\end{array}$ & 309 & 21 & 9 & 9300 & 11.6 & $\mathrm{~T} 2$ & $\begin{array}{l}\text { Segmental hepatectomy, roux- } \\
\text { en-y hepaticojejunostomy and } \\
\text { hilar lymph node dissection }\end{array}$ & $\begin{array}{l}\text { Expired } 3 \text { months } \\
\text { after surgery }\end{array}$ \\
\hline $49 / \mathrm{F}$ & $\begin{array}{l}\text { Abdominal } \\
\text { Pain }\end{array}$ & $\begin{array}{c}\text { Wall } \\
\text { thickening }\end{array}$ & 258 & 25 & 19 & 7400 & 10.9 & $\mathrm{~T} 2$ & $\begin{array}{l}\text { Segmental hepatectomy, roux- } \\
\text { en-y hepaticojejunostomy and } \\
\text { hilar lymph node dissection }\end{array}$ & $\begin{array}{l}\text { Expired } 1 \text { day } \\
\text { after secondary } \\
\text { surgery }\end{array}$ \\
\hline $80 / \mathrm{F}$ & $\begin{array}{l}\text { Abdominal } \\
\text { Pain }\end{array}$ & Normal & 163 & 49 & 23 & 10800 & 8.2 & $\mathrm{~T} 2$ & $\begin{array}{l}\text { Segmental hepatectomy, roux- } \\
\text { en-y hepaticojejunostomy }\end{array}$ & $\begin{array}{l}\text { Expired } 1 \text { day } \\
\text { after secondary } \\
\text { surgery }\end{array}$ \\
\hline $67 / F$ & $\begin{array}{l}\text { Abdominal } \\
\text { Pain }\end{array}$ & Normal & 492 & 187 & 142 & 5300 & 11.5 & $\mathrm{~T} 1$ & - & Alive \\
\hline $59 / \mathrm{M}$ & $\begin{array}{l}\text { Abdominal } \\
\text { Pain }\end{array}$ & Normal & 269 & 9 & 10 & 7400 & 12 & $\mathrm{~T} 1$ & - & Alive \\
\hline $56 / \mathrm{F}$ & $\begin{array}{l}\text { Abdominal } \\
\text { Pain }\end{array}$ & Stones & 280 & 251 & 181 & 14300 & 10.3 & $\mathrm{~T} 2$ & $\begin{array}{l}\text { Segmental hepatectomy, roux- } \\
\text { en-y hepaticojejunostomy }\end{array}$ & $\begin{array}{c}\text { Expired a few } \\
\text { days after } \\
\text { secondary surgery }\end{array}$ \\
\hline $32 / \mathrm{M}$ & $\begin{array}{c}\text { Abdominal } \\
\text { pain, jaundice }\end{array}$ & Stones & 589 & 41 & 21 & 13100 & 12.8 & $\mathrm{~T} 1$ & - & Alive \\
\hline $82 / \mathrm{M}$ & $\begin{array}{l}\text { Abdominal } \\
\text { Pain }\end{array}$ & Stones & 257 & 61 & 22 & 7500 & 10.9 & $\mathrm{~T} 1$ & - & Alive \\
\hline $55 / \mathrm{M}$ & $\begin{array}{l}\text { Abdominal } \\
\text { Pain }\end{array}$ & Stones & 214 & 19 & 24 & 3700 & 12.9 & $\mathrm{~T} 2$ & $\begin{array}{l}\text { Segmental hepatectomy, roux- } \\
\text { en-y hepaticojejunostomy and } \\
\text { hilar lymph node dissection }\end{array}$ & Alive \\
\hline $74 / \mathrm{F}$ & $\begin{array}{l}\text { Abdominal } \\
\text { Pain }\end{array}$ & Stones & 213 & 25 & 23 & 6300 & 13.7 & $\mathrm{~T} 1$ & - & Alive \\
\hline
\end{tabular}

$1 \mathrm{ALP}=$ Alkaline Phosphatase $($ normal $<360 \mathrm{IU} / \mathrm{L})$

2 ALT $=$ Alanine Aminotransferase $($ normal $<40 \mathrm{IU} / \mathrm{L})$

$3 \mathrm{AST}=$ Aspartate Aminotransferase $($ normal $<40 \mathrm{IU} / \mathrm{L})$

$4 \mathrm{WBC}=$ White Blood cell (normal $=3500-10000 / \mathrm{mL})$

$5 \mathrm{Hb}=$ Hemoglobin $($ normal $=$ male: $14-16 \mathrm{gr} / \mathrm{dL}$, female $=12-14 \mathrm{gr} / \mathrm{dL})$

of incidental gall bladder adenocarcinoma from all over from different parts of the world. There is not a uniform the world. Overall the percentages seem to be $0.2-2.5 \%$ distribution according to ethnic or geographic diversity. ${ }^{2-11}$ 
Table 2: Different reports about the frequency of incidental gall bladder adenocarcinoma from different geographic areas of the world

\begin{tabular}{lccc}
\hline Country & Year & Author & Incidence \\
\hline Brazil $^{2}$ & 2015 & Martins-Filho ED et al & $0.34 \%$ \\
\hline Italy $^{3}$ & 2013 & Panebianco A et al & $0.5 \%$ \\
\hline UK $^{4}$ & 2015 & Emmett CD et al & $0.25 \%$ \\
\hline Greece $^{5}$ & 2013 & Ioannidis O et al & $0.2 \%$ \\
\hline Bosnia and Herzegonia $^{6}$ & 2010 & Mitrović F et al & $0.54 \%$ \\
\hline Turkey $^{7}$ & 2016 & Düzköylü Y et al & $0.2 \%$ \\
\hline Korea $^{8}$ & 2016 & Ahn Y et al & $1.5 \%$ \\
\hline Nepal $^{9}$ & 2011 & Ghimire P et al & $1.28 \%$ \\
\hline Japan $^{10}$ & 2008 & Shimizu T et al & $0.83 \%$ \\
\hline India $^{11}$ & 2014 & Waghmare RS et al & $2.59 \%$ \\
\hline Current Study (IRAN) & Geramizadeh B et al & $0.37 \%$ \\
\hline
\end{tabular}

Radiological and clinical features of benign gall bladder disease can mask gall bladder adenocarcinoma, which causes mistaken diagnosis of cholelithiasis and cholecystitis instead of gall bladder cancer. The clinical features are very similar in early stages of cancer and benign diseases. . $^{4-9}$

The most common ultrasonographic finding in gall bladder cancer is wall thickening and it is very rare for gall bladder cancer to create a definite mass. ${ }^{12,13}$ In our study only six cases out of the 18 incidental gall bladder cancers (30\%) showed mild gall bladder wall thickening and in all the others, there was just cholelithiasis or completely normal gall bladder, which makes it impossible to diagnose a cancer based on sonographic findings before surgery. ${ }^{14,15}$

The diagnosis of gall bladder cancer by computed tomography (CT) is accurate and reliable; however the ability to identify early-stage cancer on $\mathrm{CT}$ is still not promising and its accuracy is about $85 \% .{ }^{16}$ Most of the incidental gall bladder cancers are early stage and in our cases also all of the incidental gall bladder adenocarcinomas were either $\mathrm{T} 1$ or $\mathrm{T} 2$. According to the recent consensus, simple or laparoscopic cholecystectomy is an adequate procedure for T1 stage. Radical surgery is necessary for T2 and higher stages using segmental hepatectomy as well as hilar lymphadenectomy. ${ }^{17-20}$

Despite the re-operation and extended surgery in $\mathrm{T} 2$ cases, their prognosis was poor and only $25 \%$ of them were alive and symptom free. It was the opposite to T1 cases for whom simple cholecystectomy was performed without re-operation and further procedure, but in the follow-up period all were alive and symptom-free. It seems that stage of gall bladder cancers is the most important predictor of surgery after cholecystectomy. ${ }^{21}$

There is a limitation in our study as we did not have the body mass indexes of the patients to assess them as a risk factor.

\section{CONCLUSION}

Incidental gall bladder adenocarcinoma is a rare event, and there is no definitely identifiable symptom and sign for prediction of this disease in the cases operated on with the impression of benign gall bladder diseases especially cholelithiasis and cholecystitis. Radiological findings including ultrasonography and CT would not add much information before surgery, in early stages of gall bladder cancer. The most important predictor of prognosis in incidental gall bladder cancer is the stage of the tumor. $\mathrm{T} 1$ cases have better prognosis even with simple or laparoscopic cholecystectomy.

\section{ETHICAL APPROVAL}

There is nothing to be declared.

\section{CONFLICT OF INTEREST}

The authors declare no conflict of interest related to this work.

\section{REFERENCES}

1. Genç V, Onur Kirimker E, Akyol C, Kocaay AF, Karabörk A, Tüzüner A, et al. Incidental gallbladder cancer diag- 
nosed during or after laparoscopic cholecystectomy in members of the Turkish population with gallstone disease. Turk J Gastroenterol 2011;22:513-6. doi:10.4318/ tjg.2011.0250.

2. Martins-Filho ED, Batista TP, Kreimer F, Martins AC, Iwanaga TC, Leão Cde S. Prevalence of incidental gallbladder cancer in tertiary-care hospital from Pernambuco, Brazil. Arq Gastroenterol 2015;52:247-9. doi:10.1590/ S0004-28032015000300017.

3. Panebianco A, Volpi A, Lozito C, Prestera A, Ialongo P, Palasciano N. Incidental gallbladder carcinoma: our experience. G Chir 2013;34:167-9.

4. Emmett CD, Barrett P, Gilliam AD, Mitchell AI. Routine versus selective histological examination after cholecystectomy to exclude incidental gallbladder carcinoma. Ann R Coll Surg Engl 2015;97:526-9. doi:10.1308/rcsann.2015.0013.

5. Ioannidis O, Paraskevas G, Varnalidis I, Ntoumpara M, Tsigkriki L, Gatzos S, et al. Primary gallbladder cancer discovered postoperatively after elective and emergency cholecystectomy. Klin Onkol 2013;26:31-4. doi: 10.14735/amko201331.

6. Mitrović F, Krdzalić G, Musanović N, Osmić H. Incidental gallbladder carcinoma in regional clinical centre. Acta Chir Iugosl 2010;57:95-7. doi:10.2298/ACI1002095M.

7. Düzköylü Y, Bektaş H, Kozluklu ZD. Incidental gallbladder cancers: Our clinical experience and review of the literature. Ulus Cerrahi Derg 2015;32:107-10. doi: 10.5152/ UCD.2015.2750.

8. Ahn Y, Park CS, Hwang S, Jang HJ, Choi KM, Lee SG. Incidental gallbladder cancer after routine cholecystectomy: when should we suspect it preoperatively and what are predictors of patient survival? Ann Surg Treat Res 2016;90:131-8. doi:10.4174/astr.2016.90.3.131.

9. Ghimire P, Yogi N, Shrestha BB. Incidence of incidental carcinoma gall bladder in cases of routine cholecystectomy. Kathmandu Univ Med J (KUMJ) 2011;9:3-6. doi: 10.3126/kumj.v9i2.6278.

10. Shimizu T, Arima Y, Yokomuro S, Yoshida H, Mamada Y, Nomura $\mathrm{T}$, et al. Incidental gallbladder cancer diagnosed during and after laparoscopic cholecystectomy. J Nippon Med Sch 2006;73:136-40. doi:10.1272/jnms.73.136.

11. Waghmare RS, Kamat RN. Incidental Gall Bladder Carcinoma in Patients Undergoing Cholecystectomy: A Report of 7 Cases. J Assoc Physicians India 2014;62:793-6.

12. Rammohan A, Cherukuri SD, Sathyanesan J, Palaniappan $\mathrm{R}$, Govindan M. Incidental gall bladder cancers: Are they truly incidental? World J Gastrointest Oncol 2014;6:4413. doi:10.4251/wjgo.v6.i12.441.

13. Zhu JQ, Han DD, Li XL, Kou JT, Fan H, He Q. Predictors of incidental gallbladder cancer in elderly patients. Hepatobiliary Pancreat Dis Int 2015;14:96-100. doi:10.1016/ S1499-3872(14)60292-7.

14. Kapoor VK. Incidental gallbladder cancer. Am J Gastroenterol 2001;96:627-9. doi:10.1111/j.1572-0241.2001.03597.x.
15. Hamdani NH, Qadri SK, Aggarwalla R, Bhartia VK, Chaudhuri S, Debakshi S, et al. Clinicopathological study of gall bladder carcinoma with special reference to gallstones: our 8-year experience from eastern India. Asian Pac J Cancer Prev 2012;13:5613-7. doi:10.7314/ APJCP.2012.13.11.5613.

16. Utsumi M, Aoki H, Kunitomo T, Mushiake Y, Yasuhara I, Arata T, et al. Evaluation of surgical treatment for incidental gallbladder carcinoma diagnosed during or after laparoscopic cholecystectomy: single center results. BMC Res Notes 2017;10:56. doi:10.1186/s13104-017-2387-1.

17. Tsirlis T, Ausania F, White SA, French JJ, Jaques BC, Charnley RM, et al. Implications of the index cholecystectomy and timing of referral for radical resection of advanced incidental gallbladder cancer. Ann $R$ Coll Surg Engl 2015;97:131-6. doi:10.1308/00358841 4X14055925060073.

18. Borreca D, Balcet F, Bona A, Bossotti M, Paolis PD. Radical Surgery for Incidental Gallbladder Carcinoma. Which Subset of Patients is Really Suitable for? J Gastrointest Dig Syst 2015;5:328. doi:10.4172/2161-069X.1000328.

19. Cavallaro A, Piccolo G, Di Vita M, Zanghì A, Cardì F, Di Mattia P, et al. Managing the incidentally detected gallbladder cancer: algorithms and controversies. Int J Surg 2014;12 Suppl 2:S108-19. doi:10.1016/j.jjsu.2014.08.367.

20. Choi KS, Choi SB, Park P, Kim WB, Choi SY. Clinical characteristics of incidental or unsuspected gallbladder cancers diagnosed during or after cholecystectomy: a systematic review and meta-analysis. World $J$ Gastroenterol 2015;21:1315-23. doi:10.3748/wjg.v21.i4.1315.

21. Ferrarese AG, Solej M, Enrico S, Falcone A, Catalano S, Pozzi G, Marola S, Martino V. Diagnosis of incidental gallbladder cancer after laparoscopic cholecystectomy: our experience. BMC Surg 2013;13 Suppl 2:S20. doi: 10.1186/1471-2482-13-S2-S20. 